\title{
A paradox resolved: Sulfide acquisition by roots of seep tubeworms sustains net chemoautotrophy
}

\author{
John K. Freytag*†, Peter R. Girguis ${ }^{\ddagger}$, Derk C. Bergquist*, Jason P. Andras*, James J. Childress ${ }^{\ddagger}$, and Charles R. Fisher* \\ *Department of Biology, Pennsylvania State University, 208 Mueller Laboratory, University Park, PA 16802; and ₹Department of Ecology, Evolution, and \\ Marine Biology, University of California, Santa Barbara, CA 93106
}

Edited by George N. Somero, Stanford University, Pacific Grove, CA, and approved September 6, 2001 (received for review December 12, 2000)

Vestimentiferan tubeworms, symbiotic with sulfur-oxidizing chemoautotrophic bacteria, dominate many cold-seep sites in the Gulf of Mexico. The most abundant vestimentiferan species at these sites, Lamellibrachia cf. luymesi, grows quite slowly to lengths exceeding 2 meters and lives in excess of 170-250 years. $L$. cf. luymesi can grow a posterior extension of its tube and tissue, termed a "root," down into sulfidic sediments below its point of original attachment. This extension can be longer than the anterior portion of the animal. Here we show, using methods optimized for detection of hydrogen sulfide down to $0.1 \mu \mathrm{M}$ in seawater, that hydrogen sulfide was never detected around the plumes of large cold-seep vestimentiferans and rarely detectable only around the bases of mature aggregations. Respiration experiments, which exposed the root portions of $L$. cf. luymesi to sulfide concentrations between 51-561 $\mu \mathrm{M}$, demonstrate that $L$. cf. luymesi use their roots as a respiratory surface to acquire sulfide at an average rate of 4.1 $\mu \mathrm{mol} \cdot \mathrm{g}^{-1} \cdot \mathrm{h}^{-1}$. Net dissolved inorganic carbon uptake across the plume of the tubeworms was shown to occur in response to exposure of the posterior (root) portion of the worms to sulfide, demonstrating that sulfide acquisition by roots of the seep vestimentiferan $L$. cf. luymesi can be sufficient to fuel net autotrophic total dissolved inorganic carbon uptake.

$\mathbf{H}$ ydrothermal vent and hydrocarbon seep environments support large communities sustained by chemoautotrophy, which is in turn based on local sources of reduced chemicals (1). Vestimentiferan tubeworms are the most conspicuous organisms at many of the hydrothermal vent sites in the eastern Pacific as well as many of the cold-seep sites in the Gulf of Mexico $(2,3)$. All vestimentiferans harbor chemoautotrophic bacterial endosymbionts and live autotrophically with hydrogen sulfide as their energy source $(4,5)$. The vestimentiferan Riftia pachyptila inhabits ephemeral hydrothermal vent habitats and is reported to be among the fastest growing of invertebrates, reaching tube lengths of $1.5 \mathrm{~m}$ and sexual maturity in 2 years (6). R. pachyptila thrives in areas of the vent field where warm sulfide-rich hydrothermal fluids rise and actively mix with the overlying oxic bottom water, and it obtains both the hydrogen sulfide and oxygen required by the symbiosis directly across its plume (4, 7-9).

Lamellibrachia cf. luymesi is the dominant species of vestimentiferan found at most of the known cold-seep sites at less than 1,000-m depth on the upper continental slope in the Gulf of Mexico (10-12). Single aggregations of tubeworms at these cold-seep sites normally contain between 500-2,000 individuals; however, some aggregations include hundreds of thousands of individuals and cover areas as great as 1,600 $\mathrm{m}^{2}$ (11). In comparison to its vent relative $R$. pachyptila, $L$. cf. luymesi grows quite slowly, averaging about $1 \mathrm{~cm}$ per year, and lives in excess of $170-250$ years $(13,14)$.

Based on studies of $R$. pachyptila, it was expected that other vestimentiferans would exclusively use their plumes for gas exchange, including acquisition of sulfide from the environment (4). A paradox emerged in the understanding of seep vestimentiferan physiology when investigators consistently discovered that sulfide was generally undetectable (with detection limits between $2-10 \mu \mathrm{mol} \mathrm{l}^{-1}$ ) around the plumes of vestimentiferan tubeworms in the Gulf of Mexico (15-17). In retrospect, this absence of detectable sulfide is not surprising as the sulfide that supports tubeworm communities at cold-seeps in the Gulf of Mexico is produced biogenically in shallow sediments (18), and seeping pore fluids are not warm and buoyant like those that bathe the plumes of hydrothermal vent vestimentiferans. There now exists a substantial body of circumstantial evidence suggesting that mature L. luymesi take up sulfide from the environment by using the posterior extension of their tubes and tissue, which Julian et al. (17) have termed a "root." These authors report that posterior roots extend into the sediment below the original point of attachment and that these buried root tubes are 700 times more permeable to hydrogen sulfide than the more robust anterior portions of the tubes, which extend upwards into the water column. They also report that although sulfide was often undetectable in pore waters $5-10 \mathrm{~cm}$ beneath mature tubeworm aggregations (16), concentrations as high as $2,700 \mu \mathrm{M}$ were present in water samples collected among the buried posterior ends of the tubeworms at greater depths in the sediments (17).

Here we present two independent data sets supporting the hypothesis that $L$. cf. luymesi use the posterior portions of their tubes to acquire sulfide in situ. First, because the very high affinity of vestimentiferan hemoglobin for sulfide would allow uptake from very low environmental levels (19), we use a very sensitive sampling and analysis technique to confirm that at most, very low $(<0.1 \mu \mathrm{M})$ levels of sulfide are present around the plumes of mature cold-seep vestimentiferans. Second, we demonstrate that in the laboratory, L. cf. luymesi take up sufficient sulfide across posterior portions of their tubes and bodies to support net autotrophic carbon uptake by the intact symbiosis. Although these results do not indicate to what extent seep vestimentiferans rely on their roots for sulfide acquisition in situ, they do demonstrate a need for a subsurface sulfide uptake mechanism and that a viable mechanism exists.

\section{Methods}

Water samples were taken through small-diameter polyetheretherketone (PEEK) tubing directly into a syringe in the rear chamber of the DSRV Johnson Sea Link (20) during a July 1998 research expedition. The samples were taken from among 4 young aggregations (largest animals $<0.5 \mathrm{~m}$ in length) and 8 mature aggregations (largest animals $>1.0 \mathrm{~m}$ in length). At each aggregation, water samples were taken from around the plumes of animals, near the sediment-water interface at the base of the aggregations, and approximately halfway between plume level and sediment level among the tubes of the animals. Total sulfide was quantified by using a modification of the methods of Singh

This paper was submitted directly (Track II) to the PNAS office.

Abbreviation: DIC, dissolved inorganic carbon.

${ }^{\dagger}$ To whom reprint requests should be addressed. E-mail: jkf124@psu.edu.

The publication costs of this article were defrayed in part by page charge payment. This article must therefore be hereby marked "advertisement" in accordance with 18 U.S.C. $\S 1734$ solely to indicate this fact. 
et al. (21). Of the sample, $700 \mu \mathrm{l}$ was immediately combined with $150 \mu \mathrm{l}$ of papain- $\mathrm{SSCH}_{3}$ solution $\left[2.0 \mathrm{mg} / \mathrm{ml}\right.$ papain- $\mathrm{SSCH}_{3}$ (Molecular Probes)/8.0 mM EDTA/60 mM NaH ${ }_{2} \mathrm{PO}_{4} / 1.0 \mathrm{mM}$ sodium acetate] under a nitrogen head and stored on ice until the end of the dive. After recovery of the submersible, the samples were incubated at room temperature for $1 \mathrm{~h}$ and then combined with $150 \mu \mathrm{l}$ of a solution of chromogenic substrate $[7.2 \mathrm{mg} / \mathrm{ml}$ $N$-benzoyl-L-arginine, p-nitroanilide (L-BAPNA) (Molecular Probes)/3 mM EDTA/150 mM Bis-Tris] for an additional hour, at which point the enzymatic digestion was stopped by addition of 5.0 $\mu \mathrm{l}$ of 1.0 mM PMSF (Roche Molecular Biochemicals). Absorbance of the samples at $410 \mathrm{~nm}$ was noted. Sulfide stock solutions (about $1 \mathrm{mM}$ ) were made up at sea from preweighed and washed sodium sulfide crystals stored in sealed vials under nitrogen and their concentrations determined by gas chromatography (22). The sulfide stock solutions were diluted to concentrations of 20 and $100 \mu \mathrm{M}$ with degassed distilled water in a glove bag under a nitrogen atmosphere and used immediately to prepare the sulfide standards $(0.1-5.0 \mu \mathrm{M})$ that were processed in parallel with the water samples. This relationship between sulfide concentration and sample absorbance was linear between $0.3-5.0 \mu \mathrm{M}$, with concentrations between $0.1-0.3 \mu \mathrm{M}$ detectable as consistent non-zero absorbance values. Samples taken between 100-400 $\mathrm{m}$ above the bottom at the beginning and end of each dive served as experimental sulfide-free controls.

Aggregations containing L. cf. luymesi and an escarpid-like species of tubeworm were collected in July 1998 from the outskirts of the Brine Pool NR1 hydrocarbon seep site in the Gulf of Mexico $\left(27^{\circ} 43^{\prime} 24^{\prime \prime} \mathrm{N}, 91^{\circ} 16^{\prime} 30^{\prime \prime} \mathrm{W}\right)$ from a depth of $640 \mathrm{~m}$. Tubeworms were collected with the DSRV Johnson Sea Link by using a hydraulically actuated net (Bushmaster Jr., Harbor Branch Oceanographic Institution, Fort Pierce, FL) that collects intact aggregations of vestimentiferans along with the carbonate rock to which the animals are attached (14). The animals were brought to the surface in a temperature-insulated box mounted on the front of the submersible and, after reaching the surface, were immediately transferred to aerated chilled $\left(7^{\circ} \mathrm{C}\right)$ seawater and held at atmospheric pressure. The blood sulfide uptake experiments were initiated at sea $24 \mathrm{~h}$ after collection of the animals used in these experiments. After returning to port, two intact aggregations of tubeworms were shipped in cold seawater to Santa Barbara, CA. At the Univ. of California, Santa Barbara, the animals were maintained in a flow-through aquarium at $5^{\circ} \mathrm{C}$. Only apparently healthy, active, and undamaged animals with intact tubes were used in this study. The first set of split-vessel respiration experiments and the balance of the blood sulfide uptake experiments were conducted within 2 weeks of collection of the animals. The second set of split-vessel respiration experiments and the undivided-vessel respiration measurements were made on animals held in the laboratory for 10 months.

Blood sulfide uptake experiments were conducted in splitvessel incubation chambers that allowed isolation of the posterior and anterior halves of the tubeworms into different pools of flowing water (3-4 $\mathrm{ml} / \mathrm{min})$. Vessel halves were constructed of polycarbonate tubing $(7.6-\mathrm{cm}$ inner diameter) that were separated by two layers of latex sheeting sandwiching $1.25 \mathrm{~cm}$ of lard, resulting in a watertight seal around the animals and between the two halves of the vessel. Single individuals or pairs of $L$. cf. luymesi were first maintained in sulfide-free seawater for a minimum of $24 \mathrm{~h}$ and then were placed into the system for periods of time ranging from 24 to $120 \mathrm{~h}$. Their roots were exposed to anoxic seawater containing dye (to confirm the integrity of the seal between chamber halves) and $500 \mu \mathrm{M}$ sulfide in the posterior half of the vessel, while the plumes of the animals were exposed to ambient surface seawater from the Gulf of Mexico $\left(\left[\mathrm{O}_{2}\right]=200 \mu \mathrm{M}\right)$ in the anterior half of the vessel.
Control animals were run in parallel and had their roots exposed to dyed deoxygenated seawater that did not contain sulfide. All experiments were conducted at $7^{\circ} \mathrm{C}$. After termination of the experiment, animals were removed from the incubation chambers and immediately killed. Samples of mixed coelomic and vascular fluids were collected, and total sulfide (free and bound) concentration was determined by gas chromatography (22).

Respiration experiments were conducted at $5^{\circ} \mathrm{C}$ at ambient pressure in split-vessel flow-through respiration chambers that were similar in design to the vessels used for the sulfide uptake experiments, except that the vessel halves had smaller interior diameters $(2.6 \mathrm{~cm})$ and the lengths were customized to accommodate the anterior or posterior of the animals in a minimum volume of water $(105 \mathrm{ml}$ in the top half and $160 \mathrm{ml}$ in the bottom half of the chamber). To assure further that no sulfide leaked into the upper half of the vessel (around the animals' plumes) during the respiration experiments, a slightly positive pressure [0.2-0.4 atmosphere $(\mathrm{atm} ; 1 \mathrm{~atm}=101.3 \mathrm{kPa})]$ was maintained between the anterior and posterior halves of the vessels when both were flowing, using back-pressure valves (Circle Seal, Corona, CA) on the respirometer chamber exit streams (Fig. 1).

For each experiment, groups of animals were placed into the split-vessel flow-through respirometry chamber, while a chamber without animals was simultaneously run in parallel as a control. The desired gas concentrations in the bottom stream of inlet water were achieved by bubbling the filtered seawater with appropriate mixtures of $\mathrm{H}_{2} \mathrm{~S}$ and $\mathrm{N}_{2}$ gases in a gas equilibrium column (23). Gas flow into the equilibration column was regulated with mass flow controllers (Sierra Instruments, Monterey, $\mathrm{CA}$ ), and the resultant concentrations of gases in the inlet water were determined by gas chromatography (22). Flow (between 1 and $3 \mathrm{ml} / \mathrm{min}$ depending on the experiment) was maintained with low pressure metering pumps (Prominent Industries, Pittburgh), and effluent streams were directed to analysis by means of stream selection valves (VICI, Houston). Flow through the chambers served as the only means of mixing inside of the chambers. The relative concentrations of dissolved inorganic carbon (DIC), $\mathrm{O}_{2}$, and $\mathrm{H}_{2} \mathrm{~S}$ in the effluent streams (experimental and control) were measured by membrane inlet MS $(23,24)$, and absolute concentrations were determined periodically by gas chromatography (22) in samples removed from the in-line sampling ports (effluent samples for calibration were taken immediately before effluent analysis by the mass spectrometer; Fig. 1). The $\mathrm{pH}$ of the seawater in the lower half of the experimental vessels ranged from 6.9 in the presence of $800 \mu \mathrm{M}$ sulfide to 8.0 in the absence of sulfide. All calibration correlations were linear within our operating range, and had $r^{2}$ values in excess of 0.90 . This system allowed the independent monitoring of oxygen, DIC, and hydrogen sulfide flux by anterior (plume) and posterior (root) portions of the worms under experimental conditions of our choosing. Each of the effluent streams (experimental and control) was analyzed for periods of 13.6 min with continuous rotation from one sample stream to another. Only data collected a minimum of $5 \mathrm{~h}$ after the animals had been introduced into this system were used for calculation of the flux rates, as this allowed the animals sufficient time to acclimate to the chamber and for the levels of gases in the effluent streams to stabilize.

Mass specific flux rates were determined by calculating the differences in dissolved gas concentrations between the experimental and control chambers, while taking into consideration flow rates and the mass of animals in the experimental chamber. During the experiments, each effluent stream was sequentially analyzed by the mass spectrometer for 13.6 min per stream (the time required for the mass spectrometer to complete 25 scans). The data acquisition software eliminated the first five scans (to allow for flushing of our membrane inlet system), and the remaining data were averaged and logged as partial pressures. 


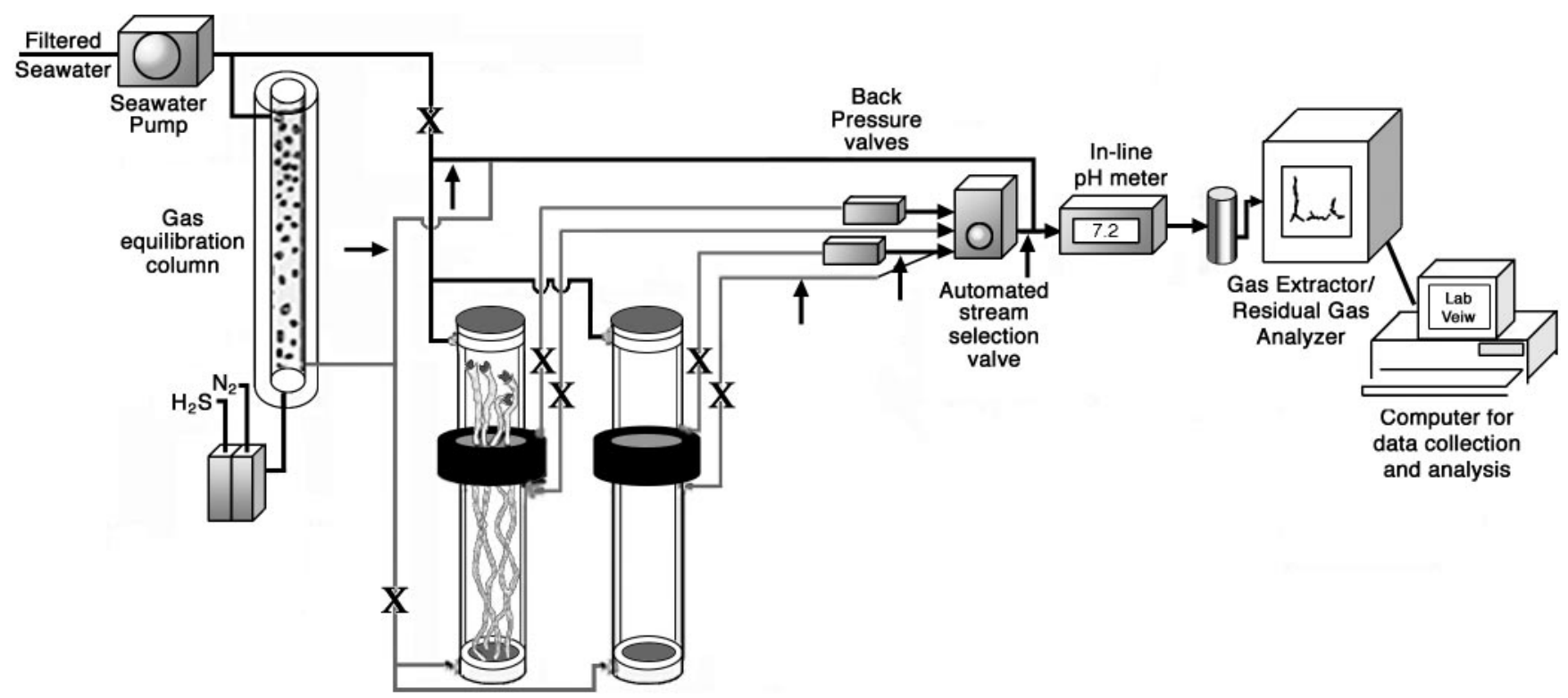

Fig. 1. Split-vessel respiration system. Arrows indicate positions of manual valves for stream selection and calibrations. Xs indicate the position of an in-line sampling port.

These data points were converted to concentrations by means of our calibration curves. Each rate ( $n$ in Tables 2 and 3 ) used to determine the average respiration rate for a given set of conditions was calculated from the difference between gas concentration values measured in control and experimental chambers in two subsequent time periods of 13.6 min, with a break of 13.6 min between each paired analysis. When conditions were not altered for several hours, these rates were averaged to yield a mean rate for a given set of conditions (Tables 2 and 3 ). Therefore, the values for $n$ given in Tables 2 and 3 are not independent experiments, but rather independent measurements made during a single extended experiment.

In a first set of respiration experiments, the apparatus was configured to alternate between analyzing gas flux in the anterior and posterior compartments of the split experimental and control vessels. The posterior ends of groups of three $L$. cf. luymesi were exposed to oxygen-free seawater containing $\approx 220$, 310 , or $430 \mu \mathrm{M}$ sulfide for at least $24 \mathrm{~h}$, while the anterior ends of the same animals were exposed to seawater containing 200 $\mu \mathrm{M}$ oxygen and no sulfide. The first group of three animals was exposed to $220 \mu \mathrm{M}$ sulfide and then removed to sulfide-free water for a period of $66 \mathrm{~h}$, while a different group of three animals was exposed to $430 \mu \mathrm{M}$ sulfide. The first group was then returned to the system and exposed to $310 \mu \mathrm{M}$ sulfide.

For the second set of experiments, the apparatus was configured to monitor only changes in the concentrations of gases around the anterior ends of a group of three $L$. cf. luymesi before, during, and after sulfide was included in the water bathing their roots. This configuration improved our power to detect differences in dissolved inorganic carbon flux, as twice the number of measurements could be made during each set of conditions. For this experiment, a different group of three L. cf. luymesi was maintained in the system for 8 days with the posterior ends of the animals exposed sequentially to anoxic sulfide-free water, anoxic sulfidic water, and anoxic sulfide-free water. To change conditions in the posterior half of the vessel, the anterior vessel half was sealed to prevent leakage from the posterior portion, and the posterior half was flushed at a rate of about $20 \mathrm{ml} / \mathrm{min}$ with the new solution for $2-5 \mathrm{~h}$. Flow rates of $1.6-2.0 \mathrm{ml} / \mathrm{min}$ were then reestablished in the upper half of the system. Rates were calculated after a minimum of an additional $5 \mathrm{~h}$ had passed to assure the system had reached equilibrium. In these experiments, sulfide levels in the posterior compartments were monitored only by gas chromatography of discrete samples (22). As an additional control, the animals were killed and removed from their tubes after the last set of experiments, and the empty tubes were returned to the respiration system and monitored for $15.5 \mathrm{~h}$.

Determining the lengths of the root portion of most individuals collected to date has proven to be very difficult as the posterior portions of all animals in most aggregations are tightly intertwined and virtually impossible to untangle. These difficulties are especially prevalent with larger animals in larger aggregations. However, $59 \mathrm{~L}$. cf. luymesi with intact roots were successfully separated from a single aggregation of young individuals, and their root and anterior tubes were measured by using twine to trace the lengths.

Statistical analyses and comparisons (two sample $t$ tests, ANOVA, regression analysis, and descriptive statistics) were calculated by using MINITAB 12 (Minitab, State College, PA).

\section{Results}

Sulfide was detected in $4(25 \%)$ of the 16 water samples taken among the tubes of vestimentiferans in young aggregations and in $4(66 \%)$ of the 6 samples taken at the sediment-water interface at the bases of these aggregations. These young aggregations occurred in areas of active seepage as evidenced by the cooccurrence of bacterial mats, partially exposed authigenic carbonates, and/or mussel beds. The highest level of sulfide in any of these water samples was $2.70 \mu \mathrm{M}$ (average $=0.53 \mu \mathrm{M}$, $\mathrm{SD}=0.91, n=22$ ). However, sulfide was never detected in water samples taken around the plumes of older (partially buried) tubeworm aggregations and was detected only rarely in samples taken halfway between the plumes and the sediment surface or even at the sediment surface in these aggregations (Table 1). In fact, four of the five water samples from mature aggregations that contained detectable levels of sulfide were taken from among one aggregation that was immediately adjacent to an aggregation of young tubeworms.

The initial blood sulfide uptake experiments confirmed that sulfide uptake across the posterior portions of live $L$. cf. luymesi could occur. Sulfide was not detectable in the blood of any of the three control animals (detection limit of $3.0 \mu \mathrm{M}$ ) but was present 
Table 1. Seawater $\mathrm{H}_{2} \mathrm{~S}$ concentrations among mature hydrocarbon seep tubeworm aggregations

\begin{tabular}{|c|c|c|c|c|}
\hline $\begin{array}{l}\text { Sample } \\
\text { location }\end{array}$ & $\begin{array}{l}\text { Range of } \\
{\left[\mathrm{H}_{2} \mathrm{~S}\right], \mu \mathrm{M}}\end{array}$ & $\begin{array}{c}\text { Samples } \\
\text { taken }\end{array}$ & $\begin{array}{l}\text { Samples with no } \\
\text { detectable } \mathrm{H}_{2} \mathrm{~S}\end{array}$ & $\%$ ND \\
\hline Water column & ND & 24 & 24 & 100 \\
\hline Plume level & ND & 17 & 17 & 100 \\
\hline Mid-aggregation & ND-0.5 & 15 & 13 & 87 \\
\hline Sediment level & ND-3.7 & 16 & 13 & 81 \\
\hline
\end{tabular}

$\mathrm{ND}$, not detected (detection limit of $0.1 \mu \mathrm{M}$ ).

in the blood of both experimental animals (152 and $170 \mu \mathrm{M})$. Even with the low level of replication, the difference between experimental and control animals was significant $(\mathrm{T}=17.67$, df $=1, P=0.036$ ).

Sulfide uptake by posterior portions of $L$. cf. luymesi occurred at all sulfide concentrations tested in the respiration experiments and was accompanied by DIC and oxygen uptake across the plumes (anterior ends) of the animals (Table 2). No DIC flux was detectable across the root portion of the worms. Before exposure of their roots to sulfide, DIC was produced and oxygen was consumed by the worms (Table 3), as is typical of heterotrophic animals. Shortly after sulfide was added to the water bathing the animals' roots, DIC flux reversed direction to net consumption (Table 3). When sulfide-free water was again supplied to the posterior chamber, oxygen consumption rates decreased sharply, and DIC flux again reversed direction to heterotrophic production over a period of about $17 \mathrm{~h}$ (Table 3 ).

The root portion of the tubes of the 59 small $L$. cf. luymesi (2.0-50.2 cm total length) from an aggregation of young animals ranged from 26 to $91 \%$ (average $=61 \%$ ) of the total tube length.

\section{Discussion}

Vestimentiferan tubeworms have no mouth or gut and obtain all of their nutrition from their symbionts. Their symbionts are sulfide-oxidizing chemoautotrophs and require sulfide to fuel autotrophic carbon fixation (and ultimately support their host; ref. 4). Any sulfide that reaches the plumes of the vestimentiferan tubeworm $L$. cf. luymesi must travel from the sediment upward through the water column. However, cold-seep fluid is not as buoyant as hydrothermal fluid, and the plumes of $L$. cf. luymesi are often located well over a meter above the sediment. As a result of spontaneous reactions between sulfide and oxygen (25), the likelihood of significant amounts of sulfide existing in bottom waters at cold-seep sites decreases as distance from the sediment-water interface increases. However, hydrothermal vent vestimentiferan blood has a high affinity for sulfide (19), and preliminary data (J.K.F., unpublished data) indicates that seep vestimentiferan hemoglobins have a similarly high affinity for sulfide. Thus, although earlier workers had found sulfide levels to be below their detection limits of $2-10 \mu \mathrm{M}$ around the plumes of seep vestimentiferans (15-17), these observations did not rule
Table 3. Plume DIC and $\mathrm{O}_{2}$ flux prior to, during, and after root $\mathrm{H}_{2} \mathrm{~S}$ exposure

\begin{tabular}{lcc} 
Experimental conditions & $\begin{array}{c}\text { DIC flux, } \\
\mu \mathrm{mol} \cdot \mathrm{g}^{-1} \cdot \mathrm{h}^{-1}\end{array}$ & $\begin{array}{c}\mathrm{O}_{2} \text { flux, } \\
\mu \mathrm{mol} \cdot \mathrm{g}^{-1} \cdot \mathrm{h}^{-1}\end{array}$ \\
\hline Before $\mathrm{H}_{2} \mathrm{~S}$ exposure & $-2.4 \pm 0.8(n=73)$ & $6.2 \pm 0.9(n=73)$ \\
$800 \mu \mathrm{M} \mathrm{H} \mathrm{H}_{2} \mathrm{~S}$ in posterior & $2.1 \pm 1.0(n=78)$ & $8.8 \pm 0.9(n=78)$ \\
$\quad$ chamber & & \\
After $\mathrm{H}_{2} \mathrm{~S}$ exposure (17 h) & $-4.9 \pm 1.8(n=38)$ & $4.7 \pm 2.3(n=38)$ \\
\hline
\end{tabular}

All data are given as mean $\pm 1 \mathrm{SD}$. Positive numbers indicate consumption and negative numbers indicate production. Each $n$ represents the number of independent calculations of flux rate for that condition as described in the text.

out the presence of sufficient sulfide around the plumes to support significant sulfide uptake rates. By using a much more sensitive sampling and analysis protocol, the highest concentration of sulfide found in water samples taken from the sedimentwater interface around mature tubeworm aggregations was 3.7 $\mu \mathrm{M}$, with $81 \%$ of water samples taken from this locale containing no detectable sulfide $(<0.1 \mu \mathrm{M})$. Not surprisingly, detection of sulfide in water samples taken halfway between the sedimentwater interface and the plumes of tubeworms in mature aggregations (0.5-0.75 $\mathrm{m}$ above the sediment-water interface) was even more rare, and the maximum concentration of sulfide detected was $0.5 \mu \mathrm{M}$. No sulfide was detected in any water sample taken from around the plumes of tubeworms in mature aggregations (Table 1). Taken together, these data offer strong support for the hypothesis that, as suggested (15-17), adult seep tubeworms must acquire sulfide from interstitial sources.

The results of the three sets of experiments in the split experimental vessels clearly demonstrate that live $L$. cf. luymesi are capable of sulfide acquisition via their roots. Furthermore, these experiments demonstrate that in the laboratory, $L$. cf. luymesi can acquire sufficient sulfide across its roots to elicit and sustain net DIC uptake (net autotrophy). The blood uptake experiments demonstrated that blood sulfide levels similar to those of freshly collected animals could result from root exposure to sulfide alone. In the split-vessel respiration experiments, all animals demonstrated net DIC uptake across their plumes when exposed to sulfide at their posterior ends only (Tables 2 and 3). When not exposed to sulfide, the animals' metabolisms are in heterotrophic poise, releasing DIC into the water. However, net DIC flux changed from positive to negative (production to consumption) when sulfide was added to the water around their posterior ends (Table 3 ). None of the gas fluxes measured during sulfide exposure were significantly correlated with posterior chamber sulfide concentrations, which is not unexpected as gas flux was measured with three different sets of animals and only four independent experiments were conducted.

Acquisition of sulfide by $L$. cf. luymesi across the root portion of its body results in the spatial separation of hydrogen sulfide uptake from oxygen uptake and may allow this species to survive

Table 2. $\mathrm{H}_{2} \mathrm{~S}$, DIC, and $\mathrm{O}_{2}$ consumption rates across root and plume of $L$. cf. luymesi

\begin{tabular}{lccr}
$\begin{array}{l}\text { Posterior } \\
\text { chamber } \\
{\left[\mathrm{H}_{2} \mathrm{~S}\right], \mu \mathrm{M}}\end{array}$ & $\begin{array}{c}\text { Root } \mathrm{H}_{2} \mathrm{~S} \text { uptake, } \\
\mu \mathrm{mol} \cdot \mathrm{g}^{-1} \cdot \mathrm{h}^{-1}\end{array}$ & $\begin{array}{c}\text { Plume DIC uptake, } \\
\mu \mathrm{mol} \cdot \mathrm{g}^{-1} \cdot \mathrm{h}^{-1}\end{array}$ & $\begin{array}{r}\text { Plume } \mathrm{O}_{2} \text { uptake, } \\
\mu \mathrm{mol}^{-1} \cdot \mathrm{g}^{-1} \cdot \mathrm{h}^{-1}\end{array}$ \\
\hline $218 \pm 82(n=7)$ & $2.9 \pm 0.3(n=19)$ & $1.1 \pm 0.3(n=28)$ & $7.2 \pm 2.3(n=28)$ \\
$307 \pm 124(n=11)$ & $4.2 \pm 0.6(n=18)$ & $2.3 \pm 0.2(n=18)$ & $5.3 \pm 1.8(n=18)$ \\
$431 \pm 103(n=7)$ & $4.7 \pm 1.1(n=39)$ & $2.7 \pm 0.1(n=24)$ & $10.4 \pm 3.4(n=24)$
\end{tabular}

All data are given as mean $\pm 1 \mathrm{SD}$. Posterior (root-containing) chamber $\mathrm{H}_{2} \mathrm{~S}$ concentration was determined periodically ( $n$ times) throughout each experiment by means of analysis of a discrete sample by gas chromatography (22). The $n$ listed for each flux rate represents the number of independent calculations of flux rate for that condition as described in the text. 
in a habitat where sulfide and oxygen do not co-exist in the water column. The ability to spatially separate the acquisition of sulfide and oxygen has been described in bivalves endemic to vent and seep habitats (26-28), and thus is not unique to $L$. cf. luymesi. However, adult $L$. cf. luymesi are much longer animals, and can potentially separate sulfide and oxygen acquisition by distances measured in meters.

Julian et al. (17) modeled root sulfide uptake by a 10 -g $L$. cf. luymesi with a $40-\mathrm{cm}$ root and concluded that sulfide sufficient to meet the animal's metabolic requirements could be taken up across the root by diffusion. This conclusion was based on the rates of sulfide diffusion across the root tube measured by the authors, an assumed metabolic rate approximately one-tenth that of $R$. pachyptila, and a variable sulfide concentration along the length of the root tube that averaged $155 \mu \mathrm{M}$ (17). The ratio of animal biomass to vessel volume necessitated by the size and shape of the experimental animals resulted in a relatively small signal in the respirometer system, and as a result the absolute rates reported here should be considered estimates. However, the sulfide and oxygen consumption rates and heterotrophic DIC production rates reported here are about $40 \%$ of those most recently reported for $R$. pachyptila (29). These lower metabolic rates are quite reasonable considering the large differences in the growth rates and environments of these two species and may be a factor in the extreme longevity of $L$. cf. luymesi $(14,30,31)$. Nevertheless, Julian et al. may have underestimated the metabolic rate of $L$. cf. luymesi in their calculations. On the other hand, measurements of the roots of very small animals and estimates of root length for larger animals indicate that even animals as small as $1 \mathrm{~g}$ can have a $40-\mathrm{cm}$ root, and larger animals have much larger roots. These two refinements to the model of Julian et al. have opposite effects of similar magnitude that offset each other, and their general conclusions stand: root sulfide uptake can be sufficient to support the sulfide demands of the association if sufficient sulfide is present (and replenished) around the animals' roots.

The animals selected for use in the respirometers were chosen because the aggregation was collected completely intact, and several of the animals could be disentangled from the rest without damaging them. The clean collection and separation of individuals from this aggregation were facilitated because the roots of the animals in this aggregation were not nearly as extensive as on most other intact aggregations successfully collected with the Bushmaster collection devices. The animals used in this study averaged about $50 \mathrm{~cm}$ in total length, approximately one-half of which was root tube. Repeated attempts to collect larger aggregations with completely intact roots have been unsuccessful and have anchored the submersible to the seafloor with the Bushmaster collection nets during the attempts. We suggest that the roots of adult $L$. cf. luymesi are not only longer than that of the hypothetical animal modeled by Julian et al. (17) but are also considerably more extensive than those of the animals used in this study, and thus are capable of even higher rates of sulfide uptake.

At this point, we have insufficient data to draw conclusions concerning the relative importance of root vs. plume sulfide uptake by seep vestimentiferans in situ. It is likely that it varies considerably between aggregations and over the life of the vestimentiferans. The vestimentiferan plume is a very efficient gas exchange organ because of its large surface area and short diffusion distances into blood spaces; if sulfide is present around the plumes of animals in an aggregation, this is likely to be the main route of sulfide uptake. Unlike in larger aggregations, sulfide is often detectable around the plumes of animals in younger aggregations, where the common cooccurrence of mussels with methanotrophic symbionts also argues for a surface expression of seepage. It is likely that substantial sulfide uptake across the plumes occurs in these young aggregations. As the tubeworms grow and the aggregations age over several centuries, surface expression of seepage diminishes and the animals' growth places their plumes as high as $1.5 \mathrm{~m}$ above the sediment. At this point, the relative importance of sulfide uptake by buried portions of their bodies should increase. Because we do not know the extent of the buried roots of adult vestimentiferans, the density of these roots, the levels of sulfide in the midst of the "rhizosphere," or the rate of sulfide replenishment in this zone, we cannot calculate in situ rates of sulfide uptake across buried roots at this time.

As noted previously, the $\mathrm{pH}$ of the seawater in the posterior compartments of the vessels ranged from 6.9 during the experiment that exposed animals to the highest levels of sulfide tested $(800 \mu \mathrm{M})$ to that of ambient seawater (about 8.0 ) when no sulfide was present. Differences in seawater $\mathrm{pH}$ shift the proportion of the sulfide species present from about $40 \% \mathrm{H}_{2} \mathrm{~S}$ and $60 \% \mathrm{HS}^{-}$ at $\mathrm{pH} 6.9$, to $5 \% \mathrm{H}_{2} \mathrm{~S}$ and $95 \% \mathrm{HS}^{-}$, at $\mathrm{pH} 8$ (32), and further preclude using this data set to investigate the relation between sulfide exposure level and gas flux rates as we do not know which species of sulfide $\left(\mathrm{H}_{2} \mathrm{~S}\right.$ or $\left.\mathrm{HS}^{-}\right)$is preferentially acquired by $L$. cf. luymesi. This variation in the $\mathrm{pH}$ of the water surrounding the posterior portions of the animals during the experiments described here may have affected the rate of sulfide uptake by the roots, but would have had no effect on the DIC species present around the plume and therefore no direct effect on DIC uptake.

That $L$. cf. luymesi maintained in the laboratory for 10 months were still capable of net autotrophy was not unexpected (Table $3)$. We have maintained $L$. cf. luymesi for over 2 years in recirculating aquaria at Pennsylvania State Univ. partially buried in sand, with sulfate-reducing bacteria producing sulfide in the sediment and active aeration-depleting sulfide that diffuses into the water column. That many of these animals have grown at both their anterior and posterior ends (J.K.F. and D.C.B., unpublished observations) is further circumstantial evidence that sulfide uptake across their roots can support net autotrophy.

This study was conducted to confirm that, at most, extremely low levels of sulfide are available to $L$. cf. luymesi at plume level in situ and to test the hypotheses that $L$. cf. luymesi is capable of using the root portion of its body to acquire sulfide at rates sufficient to sustain net autotrophic DIC uptake. The next step is to collect the data necessary to model sulfide requirements and acquisition by intact aggregations to constrain the magnitude of the importance of root sulfide uptake in situ. The morphology and extent of the buried portion (the "rootball") of larger aggregations are still almost completely unknown and are important components of a model because they will constrain the area available for sulfide uptake and intraspecific competition for buried sulfide among the individuals in an aggregation. Another key unknown at this time is the source of the deep interstitial sulfide and rates of replenishment of the rhizosphere sulfide. The primary source of sulfide at these seeps was thought to be anaerobic oxidation of seawater sulfate, but this process occurs almost exclusively in the upper $10-20 \mathrm{~cm}$ of sediment (33), and diffusion alone would be insufficient to supply significant amounts of sulfide to roots at greater depth. Other possible sources of sulfide include sulfide produced as a by-product of bacterial reduction of Castile gypsum on limestone caprock, which is often found in association with methane-rich brine reservoirs $(34,35)$, and production of sulfide from the degradation (decomposition) of buried detritus (18). An intriguing possibility suggested by Julian et al. (17) is that L. cf. luymesi releases sulfate into sediments around their roots. This could occur either through the pumping of seawater down the length of the tube by a peristaltic motion of the worm or through the directed release of the sulfate produced as a waste product of chemoautotrophic sulfide oxidation (36).

Free-living chemoautotrophic sulfide-oxidizing bacteria require access to both sulfide and oxygen, and most commonly 
occur in interface environments. These environments are normally only a few millimeters thick, although in areas where sulfide-rich waters are actively expelled into oxic waters (as at hydrothermal vents and actively venting cold seeps), both sulfide and oxygen cooccur in a much larger volume of water. At cold seeps in the Gulf of Mexico, active expulsion of seep fluid from the substrate, driven by rising methane gas and hydrocarbons, is very patchy and limited to relatively small areas within much more extensive seep communities (12). In areas of most active seepage, exposed authigenic carbonates, thick bacterial mats, mussel beds, and/or young vestimentiferan aggregations commonly occur. Existing data suggest that young seep vestimentiferans require active seepage of sulfidic fluids and acquire the sulfide required to support chemoautotrophy across their anterior plumes until posterior roots can be grown that allow interstitial sulfide sources to be tapped. Although expression of seepage at the sediment/seawater interface slows down over decadal time scales, vestimentiferan aggregations can persist for centuries, and the ability to tap deep interstitial pools of sulfide may be a key factor contributing to their remarkable longevity. With the ability to draw sulfide from well below the sulfideoxygen interface, seep tubeworms may limit the expression of sulfide at the sediment surface. They thereby exclude, by means of competition for this required resource, both mats of freeliving aerobic chemoautotrophic bacteria (which are restricted to habitats where oxygen and sulfide cooccur) as well as other symbiont-containing species that do not have the ability to acquire sulfide from as deep in the sediment. Furthermore,

1. Tunnicliffe, V. (1991) Oceanogr. Mar. Biol. Annu. Rev. 29, 319-407.

2. Hessler, R. R. \& Smithey, W. M., Jr. (1983) in Hydrothermal Processes at Seafloor Spreading Centers, eds. Rona, P. A., Boström, K., Laubier, L. \& Smith, K. L., Jr. (Plenum, New York), pp. 735-770.

3. Sibuet, M. \& Olu, K. (1998) Deep-Sea Res. 45, 517-567.

4. Childress, J. J. \& Fisher, C. R. (1992) Oceanogr. Mar. Biol. Annu. Rev. 30, 337-441.

5. Nelson, D. C. \& Fisher, C. R. (1995) in Microbiology of Deep-Sea Hydrothermal Vents, ed. Karl, D. M. (CRC, Boca Raton, FL), pp. 125-167.

6. Lutz, R. A., Shank, T. M., Fornari, D. J., Haymon, R. M., Lilley, M. D. Vondamm, K. L. \& Desbruyeres, D. (1994) Nature (London) 371, 663-664.

7. Arp, A. J., Childress, J. J. \& Fisher, C. R. (1985) Biol. Soc. Washington Bull. 6, 289-300.

8. Goffredi, S. K., Childress, J. J., Desauliniers, N. T., Lee, R. W., Lallier, F. H. \& Hammond, D. (1997) J. Exp. Biol. 200, 883-896.

9. Goffredi, S. K., Childress, J. J., Desauliniers, N. T. \& Lallier, F. H. (1997) J. Exp. Biol. 200, 2609-2616.

10. Kennicutt, M. C., II, Brooks, J. M., Bidigare, R. R., Fay, R. R., Wade, T. L. \& McDonald, T. J. (1985) Nature (London) 317, 351-353.

11. Brooks, J. M., Kennicutt, M. C., II, MacDonald, I. R., Wilkinson, D. L., Guinasso, N. L., Jr., \& Bidigare, R. R., 21st Annual Offshore Technologies Conference, May 1-4, 1989, Houston, TX, Paper 5954, pp. 663-667.

12. Sassen, R., Brooks, J. M., MacDonald, I. R., Kennicutt, M. C., II, Guinasso, N. L., Jr., \& Requejo, A. G., 43rd Annual Convention of the Gulf Coast Association of Geological Societies, October 20-22, 1993, Shreveport, LA.

13. Fisher, C. R., Urcuyo, I. A., Simpkins, M. A. \& Nix, E. (1996) Mar. Ecol. 18, 83-94.

14. Bergquist, D. C., Williams, F. M. \& Fisher, C. R. (2000) Nature (London) 403, 499-500.

15. MacDonald, I. R., Boland, G. S., Baker, J. S., Brooks, J. M., Kennicutt, M. C., II, \& Bidigare, R. R. (1989) Mar. Biol. 101, 235-247.

16. Scott, K. M. \& Fisher, C. R. (1995) Am. Zool. 35, 102-111.

17. Julian, D., Gaill, F., Wood, E., Arp, A. \& Fisher, C. (1999) J. Exp. Biol. 202, 2245-2257. because the pool of sulfidic water is tapped before it mixes with oxygen-containing waters, the tubeworms can use most of what would otherwise be lost through spontaneous reaction with oxygen in the bottom water before reaching the tubeworm's plume.

Because the adult tubeworms are obtaining sulfide before it is released from the sediment, massive aggregations of mature vestimentiferans at cold-seep sites form thickets of tubes in a relatively nontoxic environment (compared with aggregations of hydrothermal vent vestimentiferans). Thus, they provide a nontoxic area of refuge for many transient and endemic fauna. The autotrophic lifestyle, longevity, and role of cold-seep vestimentiferans in creating and providing habitat for other species suggests they are in many ways analogous to ecosystem engineering plants (sensu; ref. 37). This analogy is strengthened further by the demonstration that $L$. cf. luymesi grow posterior extensions of their bodies into the sediment and use these root-like structures to acquire essential dissolved compounds.

Special thanks are due to Mark Delacruz, Sean Murphy, Mark Van Horn, Chris Tietze, Dr. Istvan Urcuyo, Dr. Michael Arthur, Dr. Stéphane Hourdez, the Harbor Branch Oceanographic Institution, and the captains, pilots, and crew of the Research Vessel Seward Johnson and the Deep Submergence Vehicle Johnson-Sea-Link. This work was supported by the Mineral Management Service Gulf of Mexico Regional Outer Continental Shelf Office through contract number 1435-01-96-CT30813 (to C.R.F.), National Science Foundation Division of Ocean Sciences Grants 9632861 and 0002464 (to J.J.C.), and the National Oceanic and Atmospheric Administration National Undersea Research Program at the University of North Carolina, Wilmington.

18. Carney, R. S. (1994) Geo-Mar. Lett. 14, 149-159.

19. Fisher, C. R., Childress, J. J. \& Sanders, N. K. (1988) Symbiosis 5, 229-246.

20. Nix, E. R., Fisher, C. R., Vodenichar, J. \& Scott, K. M. (1995) Mar. Biol. 122, 4605-4617.

21. Singh, R., Blättler, W. A. \& Collinson, A. R. (1993) Anal. Biochem. 213, 49-56.

22. Childress, J. J., Arp, A. J. \& Fisher, C. R. (1984) Mar. Biol. 83, 109-124.

23. Kochevar, R., Childress, J. J., Fisher, C. R. \& Minnich, L. (1992) Mar. Biol. 112, 389-401

24. Girguis, P. R., Lee, R. W., Desaulniers, N., Childress, J. J., Pospesel, M., Felbeck, H. \& Zal, F. (2000) Appl. Environ. Microbiol. 66, 2783-2790.

25. Cline, J. D. \& Richards, F. A. (1969) Environ. Sci. Technol. 3, 838-843.

26. Arp, A. J., Childress, J. J. \& Fisher, C. R. (1984) Physiol. Zool. 57, 648-662.

27. Fisher, C. R. (1990) Aquat. Sci. 2, 399-436.

28. Childress, J. J., Fisher, C. R., Favuzzi, J. A. \& Sanders, N. K. (1991) Physiol. Zool. 64, 1444-1470.

29. Goffredi, S. K., Girguis, P. R., Childress, J. J. \& Desauliniers, N. T. (1999) Biol. Bull. 196, 257-264.

30. Gavrilov, L. A. \& Gavrilova, N. S. (1991) in The Biology of Life Span: A Quantitative Approach, ed. Skulachev, V. P. (Harwood, Chur, Switzerland), pp. 318

31. Finch, C. E. (1990) in Longevity, Senescence, and the Genome (Univ. of Chicago Press, Chicago), pp. 279-284

32. Millero, F. J., Plese, T. \& Fernandez, M. (1998) Limnol. Oceanogr. 33, 269-274.

33. Sassen, R., Roberts, H. H., Aharon, P., Larkin, J., Chinn, E. W. \& Carney, R. S. (1993) Org. Geochem. 20, 77-89.

34. Kirkland, D. W., Denison, R. E. \& Dean, W. E. (2000) J. Sediment. Res. 70, $749-761$.

35. Saunders, J. A. \& Thomas, R. C. (1996) Appl. Geochem. 11, 667-676.

36. Goffredi, S. K., Childress, J. J., Lallier, F. H. \& Desauliniers, N. T. (1999) Physiol. Biochem. Zool. 723, 296-306.

37. Jones, C. G., Lawton, J. H. \& Shachak, M. (1994) Oikos 69, 373-386. 